\title{
ANÁLISE DO POPULISMO NA DEMOCRACIA: ENTRE AS EMOÇÕES E O RACIONALISMO
}

\author{
ANALYSIS OF POPULISM IN DEMOCRACY: \\ BETWEEN EMOTIONS AND RATIONALISM
}

\author{
Andrey Lucas Macedo Corrêa' \\ Alexandre Walmott Borges ${ }^{2}$ \\ Karina Almeida Guimarães Pinh ${ }^{3}$
}

\begin{abstract}
RESUMO:Pretende-se, partindo dapremissa daincidência das emoçóes noestudo da teoria democrática, sobretudo no contexto atual de escalada do populismo em movimentos radicais (em ambos os polos políticos: esquerda e direita), analisar a influência das emoçóes diante da conjuntura político-institucional atual pautada na racionalidade pública. A pergunta que move a elaboraçăo do texto é: "as paixóes e emoçóes deveriam exercer algum papel na legitimidade da política democrática?" Para responder essa questăo é analisado o papel das emoçôes no cenário político contemporâneo (destacadamente no ambiente europeu) em especial no que tange aos movimentos que utilizam discursos populistas. Como resultado, busca-se um replanejamento das dimensôes e possibilidades da democracia deliberativa, abandonando teorias tradicionais quanto à racionalidade pública contrapondo-a à teoria agonística da democracia almejando uma compreensâo crítica da teoria deliberativa democrática que leve em consideraçấo o estudo das emoçóes como um dos seus pilares.
\end{abstract}

PALAVRAS-CHAVE: democracia; emoçōes; populismo; racionalidade.

ABSTRACT: It is intended, on the premise of the impact of emotions in the study of democratic theory, especially in the current context populism climbing in radical

Bacharelando em Direito pela Universidade Federal de Uberlândia-UFU com período de mobilidade internacional na Universidade de Coimbra-Portugal. Bolsista de iniciaçáo científica do Conselho Nacional de Desenvolvimento Científico e Tecnológico - CNPq e bolsista de mobilidade internacional pela UFU. Pesquisador no Centro de Estudos Sociais da Universidade de Coimbra - CES/UC e pesquisador do Laboratório Americano de Estudos Constitucionais Comparados - LAECC/PPGD-UFU. andreylucas93@hotmail.com

2 Professor Associado da Universidade Federal de Uberlândia - UFU, Professor do programa de mestrado em Direito, Uberlândia, MG, Brasil; Professor Visitante da Universidade Estadual Paulista Júlio de Mesquita - UNESP, programa de mestrado em Direito, Franca, SP, Brasil. Mestre e Doutor em Direito do Estado pela UFSC; Doutorando em História Social pela UFU; Especialista em História e Filosofia da Ciência. Coordenador do Laboratório Americano de Estudos Constitucionais Comparados - LAECC/ PPGD-UFU.walmott@gmail.com

3 Bacharel em Direito pela Pontifícia Universidade Católica do Rio de Janeiro - PUC-Rio/Brasil. Especialista em Direito Constitucional-Civil pela Universidade do Estado do Rio de Janeiro - UERJ/Brasil. Mestranda em Ciências Jurídico-políticas com mençăo em Direito Constitucional pela Universidade de Coimbra Portugal. Pesquisadora do Laboratório Americano de Estudos Constitucionais Comparados - LAECC/ PPGD-UFU pinhao.karina@gmail.com 
movements (in both political poles: left and right) to analyze the influence of emotions on the political and institutional environment current guided by a public rationality. The question that moves the work is: "the passions and emotions should play a role in the legitimacy of democratic politics?" To answer this question, we analyze the role of emotions in the contemporary political scene (notably in the European environment) in particular about the movements that using populist speeches. As a result, we seek a redesign of the dimensions and possibilities of deliberative democracy, abandoning traditional theories about the public rationality in opposition to the agonistic theory of democracy aiming for a critical understanding of democratic deliberative theory that considers the study of emotions as one of its pillars.

KEYWORDS: democracy; emotions; populism; rationality.

\section{INTRODUÇÃO}

Pretende-se, partindo da premissa da incidência das emoçóes no estudo da teoria democrática, sobretudo no contexto atual de escalada do populismo e de movimentos radicais (em ambos os polos políticos: esquerda e direita), analisar a influência das emoçōes diante da conjuntura político-institucional atual pautada na racionalidade pública. A pergunta que move a elaboraçâo do texto é: "as paixóes e as emoçôes deveriam exercer algum papel na legitimidade da política democrática?". Para responder essa questâo assinalamos o papel das emoçóes no cenário político contemporâneo (destacadamente no ambiente europeu) em especial no que tange aos movimentos com retóricas populistas. Em seguida, é realizado um questionamento em busca de uma "soluçăo" para essa relaçăo fora dos limites da democracia representativa, perpassando pela análise de propostas de democracia direta. O presente trabalho assinala que, no contexto teórico das ciências sociais e políticas, as emoçóes nunca desempenharam papel relevante, isso ocorre pelo domínio, desde a "fundaçăo" do Estado Moderno, de uma racionalidade avalorativa como sendo a base para a organizaçâo social. Entende-se que existe um desenvolvimento da ideia de democracia representativa para democracia deliberativa. Nesse segundo modelo existiria um grau maior de deliberaçấo entre os cidadáos, mas dentro da lógica liberal-racional. Essa ideia é sustentada por Mouffe (2000, p. 81) como sendo uma resposta do sistema frente aos desafios da sociedade atual, no entanto, essa ideia apenas significa uma ressurreiçấo da proposta grega antiga, nâo representando uma verdadeira oxigenaçăo do debate nem mesmo soluçōes para os conflitos emergentes (COHEN, 2003, pp. 342-361).

Como resultado busca-se um replanejamento das dimensóes e possibilidades da democracia deliberativa, abandonando teorias tradicionais quanto à racionalidade pública, em especial a teoria de John Rawls (1971), contrapondo-a com a teoria agonística da democracia de Mouffe (1993) em busca de uma compreensâo mais dialógica da teoria deliberativa democrática com relaçấo ao papel desempenhado pelas emoçóes. Para melhor abordagem do tema, o trabalho começa por analisar o contexto político dos movimentos populistas contemporâneos na Europa, analisando esses movimentos frente às teorias de racionalidade pública liberal de Rawls, contrapondo esse ponto de vista com a teoria da democracia agonística de Mouffe 
e, por fim, discorre-se sobre a importância intrínseca do estudo das emoçóes frente à conjuntura política democrática. Todo esse trabalho permeado pela análise das emoçôes em ambos os contextos, demonstrando a necessidade de expandir o foco de compreensăo do Estado e da Democracia frente ao contexto social contemporâneo.

Por fim, o trabalho busca demonstrar que carecemos de uma teoria político-institucional que parta do ser humano real e năo de uma utopia racionalista criada. Comprova-se o fértil debate sobre a temática na busca de uma racionalidade náo universal e que considere as emoçóes como inerentes ao ser, năo podendo ser dele dissociada. Apresenta-se que Boaventura de Sousa Santos caminha, pautado nas epistemologias do sul, no sentido de uma razâo quente.

\section{POVO E POPULISMO NA ATUALIDADE}

É fundamental analisar o panorama político europeu de escalada de movimentos políticos com concepçóes radicais. Essa percepçăo abrange os dois opostos do diagrama político, ou seja, emergem movimentos de esquerda e direita com ideias extremistas ${ }^{4}$. Em ambas as situaçóes um fator apresenta-se como marca comum, o populismo, que carrega consigo, intrinsecamente, uma vasta dimensăo de carga emocional, em especial a raiva e o medo conforme se apresentará adiante, ao analisarmos os movimentos radicais ${ }^{5}$ presentes em ambos os polos políticos.

Busca-se analisar detidamente cada uma das dimensóes políticas emergentes, a começar pelo radicalismo de movimentos e partidos de esquerda. Esses atores sociais apresentam como característica o protesto contra a democracia representativa e contra o modelo financeiro vigente. Os grandes movimentos dessa categoria seriam o Indignados na Espanha e o Ocuppy, que permeou vários países pelo globo, mas que teve seu centro em Nova York, em âmbito partidário talvez o exemplo mais pulsante dessa realidade seja o Podemos na Espanha. A percepçăo desses movimentos centraliza-se no fato de que a comunidade política "posta" já năo responde6 aos anseios de seu sujeito político, o povo. Esses movimentos de contestaçăo utilizam a bandeira da radicalizaçăo da democracia, contestando os pilares da democracia representativa em defesa de um modelo direto de democracia, uma "democracia real".

4 Éclaro que visôes radicais sempre existiram e sempre existirăo. Analisando o caso clássico da Revoluçâao Francesa, observa-se que existiam forças políticas para além do parlamento francês, que, assim como hoje, acreditam que a melhor organizaçăo social năo deve estar embasada em representaçăo mas sim em deliberaçăo, por isso se furtavam de atuar na lógica representativa posta.

5 A utilizaçăo autolegitimante da expressāo "Povo" năo é exclusiva dos movimentos políticos radicais, no entanto, buscamos analisar essa dimensăo detidamente tendo em vista que elas representam a luta contra o sistema posto, enquanto as demais dimensôes mais moderadas, estăo totalmente inseridas no modelo posto que apresenta grande grau de deslegitimidade.

6 Uma pergunta que extrapolaria o presente trabalho seria a análise de se em algum momento histórico a classe política posta representou os anseios de seu sujeito político, e, dessa forma, as recentes insurgências seriam provocadas por motivos além do simples descontentamento representativo e financeiro. 
Por outro lado, os movimentos (especialmente partidários) ${ }^{7}$ de extrema direita ${ }^{8}$ com viés populistas, apesar de apresentarem objetivos ideológicos diametralmente opostos às organizaçóes/partidos de extrema esquerda, carregam em sua base de pensamento o povo como combustível para defender a refundaçăo de uma identidade (nacional ou regional $\left.{ }^{9}\right)$, em contrapartida a posiçóes globais. No entanto, essa identidade é permeada do discurso xenofóbico, apresentando forte viés nacionalista, é utilizada uma visăo do mundo "pré-globalizaçăo"10 a qual representaria um modelo de sociedade melhor. Por outro lado, esses movimentos de extrema "direita" apresentam (em regra) oposiçấo ao atual modelo financeiro neoliberal, o qual relacionam como sendo uma consequência do fluxo migratório das últimas décadas.

Para uma definiçâo de "populismo" e de "povo" abordamos que o conceito apresenta características múltiplas e nem sempre inequívocas:

Es sabido además que el populismo es un fenómeno que tiene orígenes antiguos y geografías variadas. El mismo término lo certifica: desde la Rusia zarista con intelectuales en favor de la redención política de los mujiks, o el norteamericano People's Party que abogaba por una democracia auténtica en la que el pueblo pudiera participar directamente, hasta en Latinoamérica, dónde el termino se emplea desde los años treinta del siglo XX para designar a los partidos o movimientos con fuertes rasgos personalistas (COSSARINI \& ALONSO, 2015, p. 296)

Da mesma maneira a expressāo "povo" é igualmente múltipla em significados, a depender das circunstâncias e do "aparelhamento" do termo, sendo comumente entendido, por exemplo, como: a naçấo, o eleitorado, os cidadâos, os trabalhadores do campo, os trabalhadores da cidade etc. (BONAVIDES, 2002, pp. 81-94; CANOVAN, People, Politicians and Populism, 1984; 1999, pp. 2-16; TAGGART, 2000) . Dessa forma, o conceito de "povo" assim como o conceito de "populismo" apresenta-se caracterizado com grande trasnversalidade e elasticidade, demonstrando em vários momentos um caráter "autolegitimante".

Dessa forma, é patente que o termo "povo" reveste-se forte conteúdo emocional. Enquanto os movimentos de extrema direita, utilizando da retórica do medo, promovem um apelo pela "segurança" do "povo" frente às ameaças (em grande parte externas) como a imigraçăo por exemplo, os movimentos questionadores utilizam do mesmo termo "autolegitimante" para promover o rechaço contra a corrupçăo e a atual forma de organizaçâo política. Diante disso, observa-e que ambos os movimentos, com

$7 \quad$ É interessante analisar que os movimentos de extrema direita tendem a se organizar em formas partidárias, enquanto os movimentos de extrema esquerda buscam, em maioria, uma organizaçáo náo-partidária. Talvez a resposta para esse questionamento resida no grau de ruptura ou reforma do status quo combatido.

8 Os principais exemplos desses partidos de extrema direita na Europa seriam: a Frente Nacional Francesa, o UKIP britânico, a Liga Norte Italiana, o Amanhecer Dourado na Grécia, o Partido da Liberdade da Áustria, o Partido Popular Suíço entre outros. Cf.: COSSARINI; ALONSO, 2015. p. 295.

$9 \quad$ No caso da Uniăo Europeia é bem verdade que alguns movimentos de extrema esquerda repudiam a construçăo do ambiente europeu, nesse ponto, por uma análise superficial, poderia se dizer que os interesses dos grupos convergem, no entanto, basta uma análise mais profunda para perceber que o centros de pensamentos săo opostos, nos grupos de extrema direita existe forte rechaço às políticas de imigrantes por exemplo, promovendo uma exacerbaçăo do nacionalismo, algo que nâo ocorre nos movimentos de extrema esquerda.

10 A definiçăo da pré-globalizaçăo, no entanto, apresenta um enorme equívoco, tendo em vista que o processo de globalizaçáo náo é uma característica do tempo de formaçáo dos Estados modernos. O fenômeno da formaçăo dos Estados apenas catalisou o processo de globalizaçăo. 
ideologias praticamente antagônicas, utilizam-se dos mesmos "veículos emocionais" (COSSARINI \& ALONSO, 2015, p. 296) para justificarem seus discursos.

\section{O PAPEL DAS EMOÇÕES NA LEGITIMIDADE DA DEMOCRACIA REPRESENTATIVA}

Pautado nesses dois fenômenos políticos (povo e populismo) passamos a analisar o papel das emoçóes ${ }^{11}$ na esfera política e a legitimidade do modelo democrático posto, o representativo. Os principais sentimentos que influem na esfera política sâo o fracasso, o medo, a ira, e o descontentamento, sendo fundamental a análise desses sentimentos frente a esses novos atores sociais diante da política atual "tradicional".

Em primeiro lugar é importante ressaltar que na construçâo do discurso político dominante e basilar do Estado Moderno europeu as emoçóes foram ignoradas. Essa exclusâo (intencional) decorre do caráter valorativo das emoçóes, em contrapartida à uma racionalidade (dita) avalorativa. No entanto, emergem movimentos desde o fim do século XX que trazem o debate sobre as emoçóes para Ciência Política, desde dimensôes que as consideram na formaçâo de identidades coletivas e de vínculos sociais (AHMED, 2004), o papel dessas no processo de tomada de decisôes políticas e morais (NUSSBAUM, The therapy of desire: theory and practice in helleniscti ethics, 1994; 2001; MULDOON, 2008) e também sobre o papel das emoçóes para o bom funcionamento da razăo (DE SOUSA, 1987). Além disso, existem antropólogos e sociólogos que consideram que as emoçôes năo devem ser entendidas como estados psicológicos, mas sim como práticas sociais e culturais (HOCHSCHILD, 1983; KATZ, 1999).

Deve ficar claro que o objetivo na análise das emoçôes năo é buscar uma dimensâo valorativa das mesmas, analisando-as individualmente seja frente aos movimentos políticos. Entende-se o caráter intrínseco das emoçōes em toda organizaçăo político social, dessa forma, a negaçăo desse fator como sendo relevante gera uma dimensâo de análise político-social falsa. Diante disso, segundo as palavras de Craig Calhuon, deve-se "colocar as emoçóes em seu lugar" (CALHUON, 2001, pp. 28-29), buscando uma análise que busca transcender (sem reproduzir) o dualismo entre bom/mal presente no estudo superficial sobre as emoçōes.

Após essa análise, iniciamos a análise com enfoque em duas emoçōes específicas, a raiva e o medo. Essas duas emoçôes săo atemporais, estăo presentes em várias dimensôes da história humana e é transversal à organizaçăo em sociedade. No século XXI essas duas emoçôes estâo presentes tanto no norte-global quanto no sul-global, revelando verdadeiro caráter de universalidade: ${ }^{12}$

\footnotetext{
11 No âmbito da discussāo conceitual-filosófica é importante apresentar a diferenciaçāo entre "sentimento" e "emoçâo" trazida por Han. Para o autor, os conceitos apresentam diferenças nos graus de narratividade e de temporalidade. Os sentimentos carregam consigo maior grau de narratividade e de temporalidade, permite uma narraçăo, enquanto as emoçôes nâo, essas săo mais perenes, de curta duraçăo. Cf.: (HAN, 2014, pp. 65-75)

12 O termo é aqui utilizado tendo em vista que, mesmo em sociedades em que o medo e a raiva estejam em um nível diferente de compreensâo diferente da lógica ocidental, como no Tibete, esses povos sâo vítimas de discursos de raiva por outros povos. Dessa forma, seja por ser opressor ou oprimido o medo e a raiva afetam quaisquer organizaçôes humanas.
} 
De manera particular a raíz de los ataques terroristas en 2001 y la así llamada "guerra contra el terror, el miedo se ha convertido en el eje de análisis de diferentes cuestiones de alcance internacional, como la inmigración, el terrorismo y hasta las enfermedades globais (COSSARINI \& ALONSO, 2015, p. 298).

Dessa forma, os ataques terroristas de 2001 catalisaram o papel do medo a nível global. Além dessa perspectiva do norte-global, o medo encontra grande matéria e subsídio no debate sobre a segurança pública, em especial nos países do sul global, esse discurso, em que pese "autolegitimante", gera enorme influência na lógica estatal de políticas públicas dos países afetados, o que, em grande parte, reflete-se em diversos âmbitos a nível global.

Além do medo, a raiva encontra papel de centralismo quanto à análise político-social. A raiva ${ }^{13}$ apresenta uma dimensăo dupla de análise, segundo Martha Nussbaum a referida emoçâo pode representar uma rebeliâo (uma paixăo) contra a injustiça e opressăo e pode representar uma perda da racionalidade com forte poder destrutivo (NUSSBAUM, The therapy of desire: theory and practice in helleniscti ethics, 1994, p. 403) .

Diante dessa definiçăo questiona-se: por a raiva significar um sentimento de indivíduos e grupos frente a injustiça e opressâo, seria possível analisar a genealogia da raiva para encontrar uma ideia sobre a natureza da injustiça e da opressăo em si? Da mesma forma, a raiva pode motivar uma açâo política, entăo seu estudo poderia oferecer novas dimensôes sobre o caráter dos movimentos e lutas? Muitos autores comprovam que a raiva contra as injustiças fornecem importante (e até vital) energia para muitos movimentos sociais e políticos, o valor dessa emoçáo seria por sua capacidade de comunicar e transmitir o sentido da injustiça de forma mais direta, e, ao mesmo tempo, com bases questionadoras frente à legitimidade dos poderes políticos dominantes (LYMAN, 2004, p. 133). No entanto, pela imediata relaçấo (sobretudo cultural) dessa emoçâo apenas em sua segunda vertente, qual seja, a destrutiva, essa encontra-se totalmente reduzida como foco de análise política. Quando se analisa a dimensăo da racionalidade moderna (sobretudo de base Rawlseniana) percebe-se que a exclusăo dessa e de outras emoçôes é intencional, busca-se uma racionalidade pautada no diálogo na busca pelo "bem comum", dessa forma, năo há espaço para qualquer análise quanto às emoçōes.

\section{A RACIONALIDADE EM RAWLS FRENTE À ABORDAGEM DAS EMOÇÕES E O CONTRAPONTO COM A TEORIA AGONÍSTICA DEMOCRÁTICA DE MOUFFE}

Passamos a analisar a visăo da teoria liberal clássica sobre as emoçôes. Como marco inicial apresenta-se a observaçăo de Ramon Máiz (2010, p. 16), segundo a qual, para a ótica liberal clássica, as emoçôes sâo consideradas uma ameaça, uma perspectiva externa ao "pensamento ${ }^{14 ", ~ q u e ~ o ~ c e g a, ~ p r e j u d i c a ~ o ~ j u i ́ z o . ~}$

Para analisar esse contexto, discorre-se sobre a estrutura da democracia consolidada atualmente, que é fruto do liberalismo político que, ao seu passo, assenta sua base em dimensóes normativas de justiça. Dessa forma, existem dois pilares para o

\footnotetext{
13 Como sinônimo de ira, ódio, cólera.

14 No sentido de pensamento racional.
} 
pensamento liberal: o primeiro é a clara distinçăo entre público e privado e a segunda é a prevalência do justo sobre o bom ${ }^{15}$. Nessa dimensâo, o conflito moral torna-se evidente, tendo em vista a composiçăo da sociedade de grupos e indivíduos heterógenos. Para a lógica liberal, esse conflito năo se questiona, pois considera-se que existiriam ferramentas para articular as diferenças em prol de uma convivência possível.

Para John Rawls a coexistência entre as divergências de pensamento năo apresentam uma questăo apenas referente à convivência, mas sim a um acordo racional entre os indivíduos e grupos em uma sociedade. A chave para esse acordo racional seria a ideia de uma "razâo pública", que năo corresponde a uma divisăo entre as esferas públicas e privadas, é de certa forma, uma interseçăo. Para Rawls a distinçăo entre público e nâopúblico năo coincide com a distinçăo entre público e privado, dessa forma, incorreto é se referir a uma razăo privada, o que existe, verdadeiramente, é uma razăo pública. O que serve igualmente de argumento para a exclusăo das emoçôes na teoria política liberal, tendo em vista que os indivíduos carregam as emoçóes, năo a coletividade. No entanto, a teoria de Rawls apresenta uma dicotomia falaciosa da separaçáo entre os indivíduos e a coletividade que eles compóem (RAWLS, 1993, p. 255). Em consequência, para Rawls, o jogo democrático depende da capacidade dos cidadâos de serem e agirem razoavelmente. De acordo com o autor, a legitimidade moral das decisóes também residiriam no fato dessas serem passíveis de aceitaçăo por cidadăos razoáveis. Dessa forma, para Rawls, existe uma intrínseca relaçăo entre a racionalidade e a razoabilidade, estando as decisōes imersas em uma lógica racional e dialógica, em um debate que deveria ter como base a existência de indivíduos livres e iguais ${ }^{16}$. Além disso, segundo Cossarini e Alonso os requisitos de razoabilidade seriam:

Solo son razonables aquellos ciudadanos que coinciden en señalar que ninguna doctrina comprehensiva, ninguna perspectiva moral o religiosa global suministra una condición definidora para participar o una razón para la aceptabilidad de los argumentos en el espacio público (COSSARINI \& ALONSO, 2015, p. 302).

Essa ideia de Rawls sobre um acordo razoável e racional entre cidadáos razoáveis serviu e serve de base para a maioria das teorias referentes à democracia deliberativa/ representativa. Dessa forma, a participaçăo no processo deliberativo deveria implicar necessariamente em uma "desativaçăo" das emoçôes o que ocorreria por filtros próprios da dinâmica deliberativa, excluindo as emoçôes dos debates e esfera pública, mantendo a "razáo pública" com alto grau de "pureza". Assinala-se ainda que esse pensamento baseado em Rawls encontra vários partidários que buscam ressignificar alguns de seus conceitos, mas mantendo a lógica racionalista da teoria. Entre os exemplos dessa postura destaca-se Habermas (1984) com sua teoria da açăo comunicativa, dessa forma, confirma-se a ideia de que a racionalidade que permeia as estruturas sociais atuais sâo as de matriz liberal, que continua a ser "aperfeiçoada" e reproduzida por uma vasta gama de autores.

As emoçōes (quaisquer que sejam) apresentam-se intrínsecas aos indivíduos que compóem todas as dimensóes políticas, muitas vezes essas emoçóes surgem como

15 E aqui fica claro o porquê da exclusăo das emoçóes nessa teoria, tendo em vista sua categorizaçâo valorativa.

16 Ambos os conceitos na lógica clássica, inaugurada pela Revoluçấo Francesa. 
suspeita da forma "racional" pela qual as decisôes políticas sâo tomadas. Além disso, conforme visto, as emoçôes săo em muitos casos fundacionais de movimentos políticos, dessa forma é impossível exigir que os cidadăos participem da vida/estrutura política deixando de lado essas e outras emoçôes.

Buscando um contraponto à dimensâo racionalista liberal, bem como a abordagem das emoçôes sobre um novo marco teórico, passamos a analisar a teoria agonística da democracia proposta por Chantal Mouffe. Justificamos a predileçăo de se utilizar a teoria de Mouffe invés a outros autores por esta apresentar uma teoria que contrapóe os principais pontos da visăo habermasiana, que, conforme analisado, apresenta forte matriz liberal.

Aos modelos deliberativos liberais, a autora apresenta a ideia e o projeto de uma "democracia radical e plural", entendida como uma "radicalizaçâo da tradiçâo democrática moderna" mediante "a extensâo e o aprofundamento da revoluçâo democrática" (MOUFFE, Radical Democracy or Liberal Democracy, 1996, p. 22) . No centro dessa teoria, afirma-se a ideia de que a política e a democracia săo indissociáveis do conflito, nâo podendo este ser eliminado por nenhum "processo racional de negociaçăo" (MOUFFE, Le politique et ses enjeux, 1994, p. 217), quer seja o modelo deliberativo/comunicativo de Habermas, quer sejam as dimensôes clássicas defendidas por Rawls.

Para Mouffe, o modelo de democracia deliberativa na matriz liberal apresenta ponto final (teleológico) centrado no discurso de que todo o procedimento ${ }^{17}$ tenderia necessariamente ao consenso, e ai residiria sua maior falha. Em contrapartida, a autora apresenta uma dimensăo pluralista que ultrapassa a mera perspectiva normativa, abordando também uma perspectiva empírica, como formas de organizaçăo social e valores que seriam, por natureza, conflituosos (MOUFFE, The return of the political, 1993, p. 127) . A autora apresenta uma dimensâo Schimittiana ao entender que todas as instituiçôes/organizaçóes sâo caracterizadas como relaçóes de antagonismo, com a influência de diversas forças em conflito, sendo esse conflito intrínseco à qualquer organizaçâo político ou social, nâo podendo ser eliminado (SCHMITT, 2015). Para a autora mostra-se inconciliável uma dimensăo racional nos modelos sociais, essa dimensâo de consenso náo é possível pois a dimensâo política da sociedade está intrinsecamente relacionada com o "poder", que pressupóe uma linguagem de dominaçăo, ${ }^{18}$ violência e coerçăo. A linguagem política deve deixar lastro para a indecisăo e se adapta melhor a ambientes de conflito e antagonismo.

Buscando romper o paradigma racionalista liberal, Mouffe apresenta a proposta de uma "democracia agonística". ${ }^{19}$ Busca-se analisar essa teoria para responder se ela apresenta uma alternativa ao modelo deliberativo e se propóe um novo papel para as emoçôes no sistema social. A proposta de "democracia agonística" de Mouffe passa necessariamente por:

\footnotetext{
17 Interessante que no modelo racionalista liberal apenas pode existir um procedimento e náo um processo por este significar necessariamente uma perspectiva de conflito o que náo ocorre na deliberaçấo entre os "cidadâos razoáveis".

18 Nas palavras de Nietzsche, "vontade de potência" (NIETZSCHE, 2008, p. 36)

19 A título de estudo morfológico e para elucidar o leitor, a palavra agonista vem do grego e refere-se ao engajamento ao conflito, à competiçăo.
} 
1) asumir el carácter sustantivo de nuestros principios, es decir los principios liberal-democráticos que sostiene nuestros Estados de derecho, Estos no se conciben fruto de ningún acuerdo universal ni hipotético, sino resultado de circunstancias contingentes, es decir de la expresión fáctica de unas relaciones de poder hegemónicas en un momento determinado; 2) negar la posibilidad misma de cualquier acuerdo racional y de cualquier valor epistémico del procedimiento y los resultados y 3) la convivencia en una comunidad solo puede ser entendida como la recreación de las condiciones para el agonismo. De acuerdo con Mouffe cualquier construcción de una identidad democrática "nosotros" debe construirse sobre la delimitación de un "ellos", que no debe ser interpretado como un enemigo a batir, sino como un adversario, al que se respeta, pero con el que se discrepa (COSSARINI \& ALONSO, 2015, p. 306)

Dessa forma, segundo Mouffe o pluralismo existente nas sociedades deve ser reorganizado para acomodar essa realidade conflituosa, a essa reorganizaçấo a autora define como "cidadania radical". Mouffe apresenta que essa construçáo social seria mantida, năo por uma ideia substantiva de "bem comum", mas por um reconhecimento de valores éticos e políticos comuns (MOUFFE, The return of the political, 1993, p. 67) Em lugar de buscar-se acordos e consensos frutos de sofisticados argumentos racionais, o futuro da democracia passaria por potencializar formas democráticas da individualidade pautada na prática de debate. Dessa forma, as ideias da autora seriam ferramentas para uma radicalizaçâo da democracia, pelo debate e pela participaçăo. Além disso, um dos pontos mais interessantes é que a autora enxerga o tema das emoçóes sob ótica diversa do racionalismo, nâo compreendendo-as como distorçóes ao acordo, mas como ferramentas e fatores que devem ser levados em consideraçăo ao debate, da mesma forma a ideia de populismo, que nâo é enxergada como uma patologia ao sistema democrático, mas apenas como um modo de expressâo da democracia.

Com relaçăo à dimensăo principiológica, Mouffe apresenta um conceito de cidadania que năo se baseia estritamente na análise ponderada dos princípios liberais clássicos (liberdade e igualdade), mas sim na criaçāo de um "nós", que representa uma identidade hegemônica pautada em uma visăo radical ${ }^{20}$ dos princípios da liberdade e igualdade, com capacidade suficiente para desafiar as relaçôes de dominaçấo existentes no sistema atual (MOUFFE, The return of the political, 1993, pp. 69-73) .

Mouffe avança ao desvelar o véu de "legalismo" e consenso do racionalismo liberal, no entanto, em seu modelo de ruptura para a construçáo de uma cidadania plural radical a autora esbarra em incoerências com os modelos combatidos. Em nível normativo, o "agonismo" năo oferece uma soluçăo muito destoante da proposta de Rawls, por, segundo o entendimento adotado, manter uma profunda identificaçăo com a base principiológica do liberalismo. No entanto, a maior crítica suscitada está no fato de que a teoria de Mouffe apresenta uma dimensăo de "domesticaçăo do conflito" para sua conversăo ao "agonismo". No que tange às emoçōes o debate é semelhante, năo se ignora o papel das mesmas como na lógica racionalista liberal, mas busca-se, a partir de uma constataçăo de existência e importância, modos de neutralizar as emoçóes. A principal

20 Para a autora a cidadania extrapola uma dimensāo legal, é um status de identificaçâo política. 
crítica tecida a Mouffe trata da manutençăo da necessidade de um consenso mínimo, ${ }^{21}$ dessa forma, a proposta da autora reflete-se como um "pluralismo de razoáveis", estes com menor nível de coesâo exigido por Rawls mas com uma base comum necessária para a coesăo social, qual seja uma unidade ético-política. Além disso, a autora associa os conceitos de razoável com adversário e năo-razoável com inimigo, essa associaçăo representa a possibilidade de năo se respeitar as formas nâo razoáveis, pois todas elas seriam formas de reproduçâo de discursos de dominaçăo, pois a razoabilidade para a construçáo do conceito de "nós" deve se pautar no respeito ao Estado de Direito e a consequente exclusáo de todos os grupos que náo compartilham esses valores (MOUFFE, The return of the political, 1993, pp. 70-71.) .

Dessa forma, percebe-se que para Mouffe, existe apenas a possibilidade de uma democracia agonística entre pessoas que compartilham um centro comum de interesses e pensamentos, enquanto em Rawls a teoria é geral, mas impōe ao ser uma dimensâo racional que, ao contrário da teoria do autor, náo é intrínseca à realidade humana nem mesmo alcançável. Conclui-se nessa análise que ambas as teorias apresentam problemas insuperáveis, em um momento ou outro entram no campo da projeçăo inalcançável.

\section{CONSIDERAÇÕES FINAIS}

Após realizar a análise sobre os modelos mais influentes no tocante à teoria democrática e submete-los a análise com relaçăo à temática do populismo e das emoçóes, busca-se um enfoque nas hipóteses apresentadas. Para tal, em um primeiro momento, analisa-se a relaçăo entre as razōes e as emoçôes.

Segundo o trabalho, resta clara a relaçăo intrínseca das emoçōes com a dimensâo política, tendo em vista que aquelas estâo presentes tanto na natureza humana quanto nas organizaçôes político-sociais. As emoçóes tais como medo e raiva estăo ligadas à gênese de movimentos sociais, significando um combustível fundamental para a açăo política. Dessa forma, a legitimidade do regime democrático está intimamente relacionada com as emoçóes. A ótica racionalista que permeia o pensamento liberal vigente nos Estados de direito propóem um modelo de organizaçăo sócio-política que nâo levam em consideraçâo as emoçôes, por considerá-las prejudiciais à construçâo de uma racionalidade avalorativa pautada por indivíduos razoáveis, esses que náo deixariam que suas perspectivas individuais perpassem para a realidade pública, diante disso, configura-se uma relaçăo de năo-existência das emoçóes. Enquanto isso, a teoria de democracia radical proposta por Mouffe parte de premissa diversa no que tange as emoçóes, considerando-as intrínsecas às organizaçōes políticas permeadas pelo confronto, no entanto, tendo em vista que as emoçôes podem interferir no consenso mínimo que deve permear a sociedade democrática "agonística", elas devem ser contornadas. Dessa forma, para Mouffe, as emoçōes assumem uma dimensăo de năo-relevância, ou melhor, um processo de domesticaçăo das emoçóes para a existência do modelo teórico proposto pela autora.

\footnotetext{
21 Esse consenso nâo é, segundo entendimento adotado, mínimo, pois exige a existência de um consenso assentado sobre instituiçôes que constituem a democracia e sobre valores éticos e políticos nas associaçôes políticas.
} 
Diante dessas conclusóes, aponta-se a incapacidade dos dois modelos analisados de englobarem as emoçôes em seus sistemas. O máximo alcançado está no modelo de "democracia agonística" que consideram as emoçôes como intrínsecas e basilares nos processos sociais, mas que, por sua natureza instável devem ser domesticadas para o sucesso do modelo ${ }^{22}$.

Avançando para a análise do populismo, ${ }^{23}$ ambos os modelos falham em englobar essa nova conjuntura política em seus sistemas. O modelo racionalista de Rawls se transforma em uma dita "democracia deliberativa", que aprofunda as relaçóes entre os cidadăos e exige maior grau de razoabilidade no discurso, algo que nem os movimentos questionadores de extrema esquerda, nem os movimentos de extrema direita, que utilizam do discurso populista estâo dispostos a aceitar. Enquanto isso, o modelo de democracia agonística de Mouffe trata da questăo de forma preocupante. A autora propóe um modelo que exige uma razoabilidade mínima, ${ }^{24}$ os movimentos populistas radicais (tanto de esquerda quanto de direita) carregam uma crítica contra grande parte do sistema posto e defendem alteraçôes profundas no modelo político vigente. Nessa dimensăo, a teoria de radicalizaçáo da democracia de Mouffe, por mais que mantenha uma dimensâo pautada em princípios liberais, atende grande parte dos anseios dos movimentos de protesto (esquerda), mas năo responde aos anseios dos movimentos populistas de extrema direita. Para solucionar essa divergência a proposta da autora é a exclusâo da comunidade desses movimentos, justamente pela incapacidade de encaixá-los no sistema. Essa decisăo apresentada eleva em demasia o grau de abstrativismo e subjetivismo da teoria de Mouffe:

El resultado, por tanto, no es una sociedad armónica, sino la persistencia y el auge de profundas y agudas divisiones. (...) En nuestras actuales sociedades pluralistas, el consenso sustantivo parece por lo pronto inalcanzable. Sin embargo, el rechazo del universalismo y el consenso no debe desembocar en una concepción de la política que arroje de la comunidad política - no ya del diálogo - a los ciudadanos no razonables. (COSSARINI \& ALONSO, 2015, p. 312)

Dessa forma conclui-se qualquer que seja o modelo político adotado, a coexistência de grupos de ruptura radicais deve encontrar um limite na dimensăo institucional, como a vedaçáo aos discursos de ódio frente à liberdade de expressâo ou os sistemas para garantir a ordem democrática, sob pena de incorrer-se em dimensóes político-ideológicas que deturpam qualquer sistema que preze-se democrático.

Boaventura, apesar de náo apresentar um modelo, aponta um caminho para uma nova perspectiva de razâo, apontando uma estrutura social que deve, como transiçâo e continuamente, passar por um processo de emancipaçăo social. Para o autor as emoçóes devem assumir seu lugar, passando năo pela negaçăo da razăo estruturante (razâo fria), mas a complementando:

\footnotetext{
22 É bem semelhante à posiçăo das ciências sociais frente às dimensōes biológicas do ser humano, conforme exposto por Richard Dawkins (1974)

23 Que, conforme visto, é um conceito intimamente relacionado com as emoçōes.

24 Conforme exposto durante o texto, a diferença mais clara entre o modelo de Rawls e de Mouffe reside no grau de razoabilidade na dimensăo da cidadania.
} 
Hay una dimensión emocional en el conocimiento que nosotros manejamos muy mal, y entonces debemos ver lo que distingue las dos corrientes de nuestra vida, tanto en las sociedades como en los individuos: la corriente fría y la corriente caliente. Todos tenemos las dos: la corriente fría es la conciencia de los obstáculos, la corriente caliente es la voluntad de sobrepasarlos. Las culturas se distinguen por la primacía que dan a la corriente fría o a la corriente caliente. Pienso que la corriente fría es absolutamente necesaria para que uno no se engañe, y también la corriente caliente es muy importante para no desistir fácilmente (SANTOS, 2006, p. 49)

Outro viés de análise vital a ser estudado, náo como alternativa, mas como evidenciador das falhas nas teorias políticas existentes no que tange a natureza do "ser político" nas sociedades vem de Richard Dawkins, com sua teoria do "gene egoísta" (DAWKINS, 1974) que apresenta um forte subsídio para entender as relaçōes sociais, ao compreender dimensóes evolutivas à nível genético e social, apresentando uma nova perspectiva de análise para o "egoísmo" nas sociedades humanas para além de qualquer racionalidade liberal. Para o autor o sentido de cooperaçăo estaria ligado a uma dimensăo de recompensas e expectativas, o que, de certa forma, transpóe o centro de debate sobre as organizaçōes sociais para um polo diverso do racionalismo moderno. Apesar da análise proposta por Darwin, e, consequentemente por Dawkins, nâo permear necessariamente a política, vislumbra-se que o reconhecimento das "leis" da seleçâo natural, que tem como base, em regra, o egoísmo e a tomada de vantagem sobre o próximo para a reproduçăo apresenta um marco importante sobre quais os caminhos que a organizaçăo humana em sociedade náo deve seguir. Quaisquer dimensôes sociais e institucionais que sugiram uma lógica de seleçăo natural, tais como os regimes fascistas e nazistas, o capitalismo e suas "leis" de mercado, entre tantos outros sâo obstáculos fundamentais na construçâo de uma sociedade altruísta:

"With savages, the weak in body or mind are soon eliminated; and those that survive commonly exhibit a vigorous state of health. We civilized men, on the other hand, do our utmost to check the process of elimination; we build asylums for the imbecile, the maimed, and the sick; we institute poor-laws; and our medical men exert their utmost skill to save the life of everyone to the last moment. There is reason to believe that vaccination has preserved thousands, who from a weak constitution would formerly have succumbed to small-pox. Thus, the weak members of civilized societies propagate their kind. No one who has attended to the breeding of domestic animals will doubt that this must be highly injurious to the race of man. It is surprising how soon a want of care, or care wrongly directed, leads to the degeneration of a domestic race; but excepting in the case of man himself, hardly any one is so ignorant as to allow his worst animals to breed. The aid which we feel impelled to give to the helpless is mainly an incidental result of the instinct of sympathy, which was originally acquired as part of the social instincts, but subsequently rendered, in the manner previously indicated, more tender and more widely diffused. Nor could we check our sympathy, if so urged by hard reason, without deterioration in the noblest part of our nature (DARWIN, 1999).

Dessa forma, qualquer modelo de organizaçăo da sociedade que se proponha solidário deve sempre refletir se as organizaçōes sociais e as instituiçōes estăo permeadas ou năo de características das "leis" de seleçăo natural. Essas mesmas "leis" nos forneceram uma capacidade cerebral para pensar para além da dominaçâo e eliminaçâo intrínseca que ocorre na natureza. Assim como a seleçâo natural, as emoçôes săo um fato, estâo 
intrínsecas. A criaçăo de modelos que entendam essas dimensōes como sendo falsas estâo fadados a se distanciar da organizaçăo social. Năo oferecem respostas, mas sáo importantes pressupostos para se pensar o novo. A ciência política, o direito e a sociologia devem ser alastradas pela realidade e, a partir dela, construir o novo: um modelo político em que as emoçóes sejam entendidas, sem ser instrumentalizadas, sejam inseridas sem serem "domesticadas", sejam entendidas como a realidade e náo como a degeneraçăo do ser humano intrinsicamente racional. Os modelos de organizaçấo atual, fortemente permeados pela vitória do mais forte e avantajado adjetivando este com a alcunha de racional encontra dupla dimensăo de falsidade do que uma sociedade altruísta significa, seja por seguir as "leis" de seleçâo natural, seja por encaixar o homem em uma racionalidade desprovida de emoçôes à qual ele nunca poderá pertencer.

Mouffe encaminha sua teoria de democracia agonística em um sentido de eliminaçấo, nâo dos mais fracos, mas dos nâo alinhados ideologicamente com o modelo, abrindo uma brecha extremamente subjetiva para a re-reproduçăo dos modelos de dominaçăo e extermínio que săo características indeléveis das organizaçôes sociais humanas, aproximando-a da seleçăo natural e afastando-a da reciprocidade e altruísmo que talvez seja a chave para pensar o "novo" a nível social e institucional. Rawls, por outro lado, constrói a partir do falso, ou seja, um ser humano racional, desprovido de emoçôes, essas que sâo consideradas pelo autor como obstáculos intransponíveis para a razoabilidade, e, por isso, ignoradas. 


\section{REFERÊNCIAS BIBLIOGRÁFICAS}

AHMED, S. (2004). The cultural politics of emotion. New York: Routledge.

BONAVIDES, P. (2002). Ciência Política, 10 ed., Săo Paulo: Editora Malheiros.

CALHUON, C. (2001). Putting emotions in their place. In Goodwin, Passionate politics: emotions and social movements (pp. 45-57). Chicago: Chicago University Press.

CANOVAN, M. (1984). People, Politicians and Populism. Government and Opposition, 19, 312-327. Retrieved from Disponível em: http://onlinelibrary.wiley.com/ doi/10.1111/j.1477-7053.1984.tb01048.x/abstract

CANOVAN, M. (1999). Trust the people! Populism and the Two Faces of Democracy. Political Studies, 47, pp. 2-16. Retrieved from Disponível em: http://onlinelibrary.wiley. com/doi/10.1111/1467-9248.00184/pdf

COHEN, J. (2003). Deliberation and democratic legitimacy. In D. Matravers, \& J. Pike, Debates in Contemporary Political Philosophy: An Anthology, pp. 342-361. London: Routledge.

COSSARINI, P., \& ALONSO, R. G. (2015, abril/junho). El papel de las emociones en la teoría democrática. Desafíos para un uso público de la razón en tiempos de populismo. Revista de Estudios Políticos (Nueva Época), 168, pp. 291-315.

DARWIN, C. (1999). The Descent of Man. Gutemberg E-Books. Retrieved Março 01, 2016, from http://www.gutenberg.org/cache/epub/2300/pg2300-images.html

DAWKINS, R. (1974). The Selfish Gene. Oxford: Oxford University Press.

DE SOUSA, R. (1987). The Rationality of Emotion. Cambridge: MIT Press.

HABERMAS, J. (1984). The theory of communicative action, v. 1. Reason and the rationalizalion of society.). Boston: Beacon Press.

HAN, B.-C. (2014). Psicopolitica. Barcelona: Herder Editorial.

HOCHSCHILD, A. R. (1983). The Maneged Heart: Commercialization of Human Feeling. Berkeley: University of California Press.

KATZ, J. (1999). How Emotions Work. Chicago: University of Chicago Press.

LACLAU, E. (2005). La Razon Populista. Buenos Aires: Fondo de Cultura Economica.

LYMAN, P. (2004). The Domestication of Anger: The Use and Abuse of Anger in Politics. European Journal of Social Theory, pp. 133-147. Retrieved from disponível em: http:// est.sagepub.com/content/7/2/133.abstract

MAÍZ, R. (2010). La hazaña de la razón: la exclusion fundacional de las emociones en la teoría política moderna. Revista de Estudios Político, 149, pp. 11-45.

MOUFFE, C. (1993). The return of the political. Londres: Verso.

MOUFFE, C. (1994). Le politique et ses enjeux. Paris: La découverte/MAUSS.

MOUFFE, C. (1996). Radical Democracy or Liberal Democracy. In D. TREND, Radical Democracy: Identity, Citizenship, and the State (pp. 19-26). New York: Routledge. 
MOUFFE, C. (2000). The Democracy Paradox. London : Verso.

MOUFFE, C. (2007). Práticas artísticas y democracia agonística. Barcelona: MACBA/ $\mathrm{UAB}$.

MULDOON, P. (2008). The moral legitimacy of anger. European Journal of Social Theory, 299-314.

NIETZSCHE, F. (2008). Para além do bem e do mal. Lisboa: Guimarăes.

NUSSBAUM, M. (1994). The therapy of desire: theory and practice in helleniscti ethics. Princeton: Princeton University Press.

NUSSBAUM, M. (2001). Upheavals of Thought: The inteligence of Emotions. Cambridge: Cambridge University Press.

RAWLS, J. (1971). A Theory of Justice. Cambridge: Harvard University Press.

RAWLS, J. (1993). Political liberalism. New York: Columbia University Press.

RAWLS, J. (1993). Political Liberalism. New York: Columbia University Press.

SANTOS, B. d. (2006). Una nueva cultura política emancipatoria. In Renovar la teoría crítica y reinventar la emancipación social (encuentros en Buenos Aires). Buenos Aires.

SCHMITT, C. (2015). 0 conceito do político. Lisboa: Ediçôes 70.

TAGGART, P. (2000). Populism (Vol. III). Buckingham: Open University Press. 